Available online at

INSECTA

Integrative Science Education and Teaching Activity Journal

Journal homepage : https://jurnal.iainponorogo.ac.id/index.php/insecta

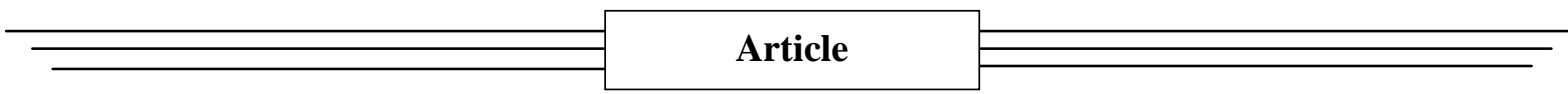

\title{
Development of Science-Literacy Based Pocket Book on Global Warming Materials for Junior High School Students
}

\author{
Sezy Silviya Ningsih ${ }^{1 *}$, A. Suhardi ${ }^{2}$ \\ ${ }^{1,2}$ Tadris Ilmu Pengetahuan Alam, UIN KHAS Jember, Indonesia \\ *email:sesisilvi09@gmail.com
}

\section{Article Info}

Article history:

Received: September 22, 2021

Accepted: October 14, 2021

Published: November 29, 2021

Keywords:

Global warming, Books

Pocket, Science Literacy.

\begin{abstract}
This study aims to describe the validity and responses of students to the development of a science literacy-based pocket book on global warming material for seventh grade of junior high school students. This research is a type of Research and Development which refers to the 4-D Thiagarajan model (Define, Design, Develop and Disseminate). The data collection instrument used a validation questionnaire conducted by the validators (materials, media and users) and a student response questionnaire through two stages, namely a small- scale response test and a large-scale response test. Based on the results of validation by material validators, media validators and users (teachers) were declared very valid with an average percentage of the three validators of $92.12 \%$. The results of the responses of small-scale students were $96.45 \%$. The large scale of $88.24 \%$ showed that the responses of students were very interesting to the development of a science literacy-based pocket book on global warming materials for junior high school students.
\end{abstract}

(C) 2021 Sezy Silviya Ningsih, A. Suhardi

\section{INTRODUCTION}

The 21st century is an increasingly difficult challenge, especially in the field of education. Therefore it is necessary to produce quality human resources so that these challenges can be overcome in real life. This also requires students to be able to apply their knowledge to solve problems in everyday life or is called scientific competence (Yuliati, 2017). Scientific literacy (SL) can be defined as an action to understand science and apply it in everyday life to be useful in the midst of people's lives (Toharudin, 2011). Scientific literacy according to the Program for International Student Assessment (PISA) is the ability to use scientific knowledge, identify questions and describe existing evidence to draw conclusions (Nofiana \& Julianto, 2018). Literacy is also defined as a person's ability to apply knowledge in everyday life and make decisions about scientific problems (Arianto \& Fauziyah, 2020). In measuring aspects of scientific literacy, PISA sets three major dimensions, namely the process of science, content of science and the context of the application of science. These dimensions are also based on scientific literacy indicators, 
namely 1) Scientific processes which include: Identifying scientific questions, explaining scientific phenomena, using scientific evidence; 2) Science content: understanding science; 3) The context of science: solving problems (Toharudin, 2011). The results of the PISA study show that the basic science education level of Indonesian students is the most lower than several participating countries in 2015 (Mustika, 2016). The low level of scientific literacy of Indonesian students can be caused by several factors that can be seen from the low quality of students' science learning, such as: the learning process that ignores the mastery of students' scientific competencies. Therefore, improvements are needed to improve the quality of science learning (Toharudin, 2011).

One of the materials that can be related to scientific literacy in science subjects is global warming. Because the material on global warming contains global issues that involve students to make decisions on these issues (Yaumi, 2017). Students can improve their mastery of science when students have a strong interest in reading, but interest in reading is still low. The low interest in reading students is caused by a lack of interest in reading books available at school. The books provided at school are considered monotonous so that students are not interested and bored. In addition, the size of the books provided in schools is less practical because they are quite large and feel heavy (Salyani et al., 2018). Therefore, it is necessary to develop a teaching material into a more practical form to make it easier for students to carry and use it. Books that have a small size are called pocket books. In general, pocket books are books that are small in size, contain information and make it easier for users to carry it anywhere and anytime (Mustari \& Sari, 2017).

The importance of teaching materials for students in successful learning can bridge experience with knowledge. Teaching materials can be in the form of whole texts that are read by students so that students can understand the contents and apply them in everyday life. So that students master science and science abilities can study science teaching materials with the following objectives. First, students master science products, such as concepts. Second, to solve science problems, scientific methods can be used. Third, after studying both students will have values related to attitude problems (Toharudin, 2011). Pocket books can be used as teaching materials because they are prepared for the process of learning activities and contain learning materials to be taught. The teaching materials themselves can be divided into two types, namely first, the main text book, which contains teaching materials for a field of study that is used as the main book for students and teachers. Second, complementary textbooks are books that are useful or additional to the main textbook and are used by teachers and students (Prastowo, 2016).

Based on initial observations, several problems emerged, namely; During learning activities, many students are passive, lazy to read, and the level of scientific literacy in grade VII is still low. Some students prefer to read in a quiet place, cannot concentrate in noisy conditions. From these problems, it is necessary to develop printed teaching materials with practical sizes so that they attract the attention of students such as pocket books. Several previous researchers have shown that pocket books are attractive to students so that they can be used in the learning process. Mardatillah explained that the identification pocket book developed was in accordance with the effective category. This effectiveness is shown by the average completeness of student learning outcomes of 87.98\% (Mardatillah, 2018). Based on the results of his research, Mustika also argues that scientific literacy-based pocket books have received a good response, so they are worthy of being used and tested in the next step (Mustika, 2019). On the other hand, Fajar argues, there is an increase in the average learning outcomes between students who use digital pocket books and those who do not use pocket books. So that it is feasible and effective to use as complementary teaching materials in helping students during the learning process (Fajar, 2018). 
According to previous researchers, there are differences, among others: the development of digital pocket books, plant identification pocket books and science literacybased pocket books. As part of the research, a pocket book based on science literacy will be developed with a pocket book size of $10.5 \mathrm{~cm} \times 17.5 \mathrm{~cm}$. The material contained in the pocket book is global warming material which is equipped with sample questions, practice questions, competency tests and mini-research. The pocket book developed in this study is made as attractive as possible so that students are more confident when using it in public places. The combination of images and text is contained in a pocket book that will be developed so that it attracts the attention of students when reading and easy to understand when learning to use a pocket book based on scientific literacy.

Pocket books not only have advantages but also disadvantages because they are printed teaching materials. There are shortcomings in the design of pocket books, such as the importance of students having the ability and speed to read; animations or videos cannot be displayed in the pocket book; While printing a pocket book takes a long time; Because, like other books, they are made of paper, pocket books can be lost and damaged if they are not stored properly (Yuliani, 2015). The pocket book developed by the researcher is a pocket book based on scientific literacy. The scientific literacy indicators used are scientific literacy according to PISA with three scientific dimensions, namely 1) The scientific process which includes: Identifying scientific questions, explaining scientific phenomena, using scientific evidence; 2) Science content: understanding science; 3) The context of science: solving problems (Toharudin, 2011).

\section{METHODS}

This research used the method Research and Development (R\&D) with 4-D. Model (Define, Design, Develop and disseminate). This research was conducted at SMP Negeri 1 Sukowono class VII, from December 2020 to April 2021. The stages of the 4-D model are as follows:

1. Define stage

At stage Define There are five main steps, namely:

a. Front-end analysis, in this step, the researcher conducts a front-end analysis with the aim of knowing the basic problems during learning so that it is necessary to develop a pocket book based on scientific literacy. This is based on the 2013 curriculum which invites students to think about science. From these problems, pocket books based on scientific literacy can help students to think about science and provoke students to be active in the classroom.

b. Analysis of students, this step aims to determine the characteristics of class VII students in the learning process.

c. Task analysis, the step contains a review of assignments in learning materials and helps researchers to formulate learning objectives when making scientific literacy-based pocket books.

d. Concept analysis, concept analysis is compiled based on the reference of Core Competence (KI) and Basic Competence (KD).

e. Formulation of objectives is the result of summary, task analysis and concept analysis to determine learning objectives as the basis for preparing instruments and designing pocket books.

2. Design stage

This stage is carried out to determine the format of a science literacy-based pocket book. Stage design There are three steps, namely:

a. Preparation of material, this step presents the formulation of learning objectives for global warming material including the greenhouse effect, understanding and causes 
global warming, the impact of global warming (global warming) and efforts to combat global warming.

b. Media selection, media selection is carried out based on a preliminary analysis that has been carried out by researchers.

c. The selection of the format is the first step in designing the initial format of the science literacy-based pocket book design.

3. Development Stage

At this stage, validation is carried out by a material validator who is a tadris science lecturer, a media valodator who has experience with media, and a science teacher as a user to determine the validity of the developed science literacy-based pocket book. Then a small-scale trial of 6 students was carried out and a large-scale trial of 30 students was carried out to determine the students' responses to science literacy-based pocket books.

4. Spread stage (disseminate)

This stage was not carried out by the researcher due to the lack of time and money owned by the researcher. In addition, it is not to find out how far the effectiveness of the learning activities developed is. However, it is only to determine the level of validity and student responses to the developed science literacy-based pocket book. The types of data used in research and development are quantitative data and qualitative data obtained from expert validation sheets and student response sheets in the form of questionnaires. Quantitative data were obtained from the results of the validity test (validator and teacher) and student response questionnaires. While qualitative data obtained from the results of comments and input from validators, teachers, and students. Before being tested on students, the results from the validator are then revised as the basis for perfecting the products that have been developed.

Data collection instruments are tools used by researchers to conduct research so that these activities become systematic and easy. The tools can be in the form of: a questionnaire; match list; scale; interview guidelines; observation sheet or observation guide; exam questions and so on (Sudaryono, 2016). In this study, a validation questionnaire and a response questionnaire were used. Questionnaire is a data collection technique by asking several questions or statement (open or closed) and written to the respondent to answer the question or statement (Sugiyono, 2017). The questionnaire used ischecklist with a score using a scale likert 1-5 adopted from Sugiyono. The criteria used in each rating scale are as follows:

\begin{tabular}{cc} 
Table 1. Pen scale criteriarating \\
\hline Criteria & Score \\
\hline Very Good & 5 \\
Good & 4 \\
Enough & 3 \\
Less & 2 \\
Very Poor & 1 \\
\hline
\end{tabular}

In addition, validation instruments were carried out to collect data so that the scientific literacy- based pocket books developed were known to be valid. At this stage the researcher gave a validation questionnaire to the validator and the product was a pocket book based on scientific literacy. After the questionnaire and the product is given, it is then given an assessment as the basis for perfecting the product developed.

The validation instrument has two indicators that are used to measure the validation instrument, namely: 1) instructional studies, which have a function to determine the suitability of the contents of a science literacy-based pocket book for class VII students in accordance with core competencies, basic competencies, indicators and learning objectives. will be achieved. In addition, it also serves to determine the truth of the material to be 
reviewed from the scientific aspect, the accuracy of examples of clarity of images and illustrations. 2) Technical study, serves to determine the visual appeal of science literacybased pocket books on global warming material with core competencies, presentation techniques, language used and so on. After the validation instrument is done, the next step is to provide the student response instrument. The instrument is given to students to fill out the questionnaire that has been given by giving a markchecklist in each row and column aspect. The statements in each row are measured based on the criteria against a science-based pocket book for class VII students. The instrument is given after students use a pocket book based on scientific literacy that has been developed. This step is carried out in order to find out the opinions of students on the development that has been carried out.

From the data that has been obtained from the validation instrument and the student response instrument, then it is analyzed using data analysis techniques. Data analysis techniques are very important activities in the research process (Setyosari, 2013). Data analysis techniques consist of: Analysis of the data from the validation results. The purpose of data analysis of the validation test results is to determine the level of validity of the scientific literacy-based pocket books that can be developed. The percentage assessment of the validation results can be obtained using the formula: $V=\frac{T_{s \Sigma}}{T_{s h}} \times 10$

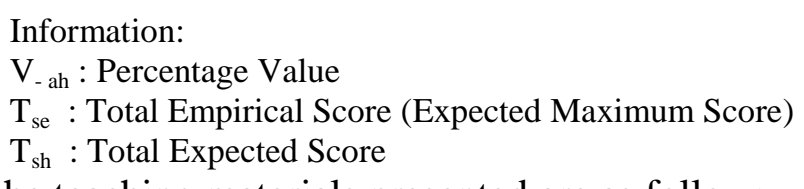

The criteria for the teaching materials presented are as follow:

Table 2. Validation Criteria

\begin{tabular}{ll}
\hline Validation criteria & Validation level \\
\hline $85,01-100,00 \%$ & Very valid or can be used without revision \\
$70,01-85,00$ & Valid or usable but need minor revision \\
$50,01-70,00 \%$ & Sufficiently valid, it is recommended not to use \\
& it because it needs a major revision \\
$01,00-50,00 \%$ & Invalid, or should not be used \\
\hline (Akbar:2016) &
\end{tabular}

The next step is data analysis techniques for student responses. The percentage of student responses who provide responses and assessments according to certain criteria uses the following formula:

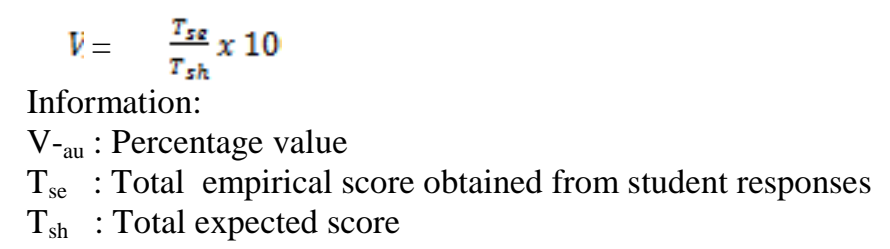

The percentage criteria obtained through student responses are presented in the from of a table as follows:

Table 3. Student response criteria and acttraktiveness

\begin{tabular}{cl}
\hline Value & \multicolumn{1}{c}{ Criteria } \\
\hline $81 \%-100 \%$ & Very interesting \\
$61 \%-80 \%$ & Interesting \\
$41 \%-60 \%$ & Quite interesting \\
$21 \%-40 \%$ & Not attractive \\
$0 \%-20 \%$ & Very unattractive \\
\hline (Akbar:2016) &
\end{tabular}

\section{RESULTS}

This research was a type of research Research and Development using a 4-D model by Thiagarajan. This research consists of four stages in which there were steps in each stage. 


\section{Define stage (define)}

Based on the results of the needs analysis that has been carried out, the overall data is obtained as follows: a) students use textbooks provided by the library and do not have other handbooks, b) lack of student interest in science subjects because they are considered difficult subjects, c) some students are lazy to read and passive when in class, d) some students prefer to read in a place where d) the scientific literacy level of class VII students is still low.

2. Material Preparation

At this stage is to determine global warming material based on scientific literacy indicators, namely the scientific process which includes: identifying scientific issues, explaining scientific phenomena and using scientific evidence. Science content and scientific context begin with things that are close to students such as activities that are in the house to explain the mechanism of the greenhouse effect (page 9). The scientific process in identifying scientific issues is clarified with features did you know?. Explaining scientific phenomena can be seen in Let's Think. Scientific evidence is found on the impact of global warming as in the science info feature that contains viruses covid-19 the virus mutation becomes more virulent due to global warming.

a. Media Selection

In selecting the media, the researcher chose to use a pocket book based on scientific literacy on global warming material. This textbook has a small size of $10.5 \mathrm{x}$ $17.5 \mathrm{~cm}$. Science literacy-based pocket books are one of the complementary teaching materials because they are an addition to the main textbook and are used by teachers and students (Prastowo, 2016). During making media, researchers use applications Microsoft Word 2007and Coreldraw X7, written using the font Arial and Book Antiqua 11 pt size, and printed using 75 gram A4 paper for content, paper ArtPapper 230 grams for cover. Microsoft Word 2007 is one of the applications of Microsoft Office 2007 used to process words (Setyawan, 2018). Application Microsoft Word 2007 what the researcher uses is to compile the material (content) in a science literacy-based pocket book which is then transferred to the application Corel Draw X7. Coreldraw X7 is a graphics-based program vector which is commonly used to design various works of art such as logos, brochures and others (Atika, 2019). Researchers useCoreldraw X7 to design cover and the inside (contents) of the developed science literacy-based pocket book.

b. Format Selection

The choice of format in developing a science literacy-based pocket book is made as attractive as possible, equipped with full color and pictures that represent global warming material based on scientific literacy. In addition, it is also equipped with various questions, both independent assignments, practicum (mini-research) and group assignments.

c. Initial Design

The initial design is a step that contains the design of a scientific literacy-based pocket book that is used to obtain the data needed during the development process. The design of a scientific literacy-based pocket book refers to the previous stages and steps. The design of a scientific literacy-based pocket book is also based on the characteristics of students who have been analyzed, namely more interested and happy with material related to everyday life. The initial design for the development of a science literacy-based pocket book can be seen in table 4 below: 
Table 4. Initial Design of a Science Literacy-Based Pocket Book

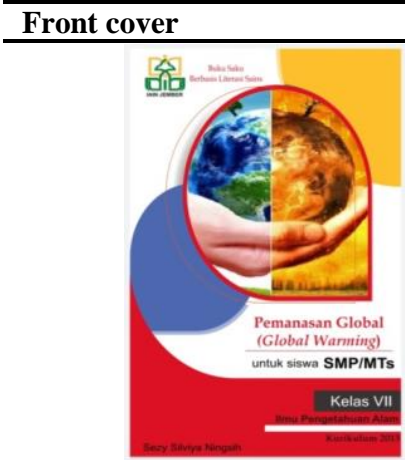

Table of contents
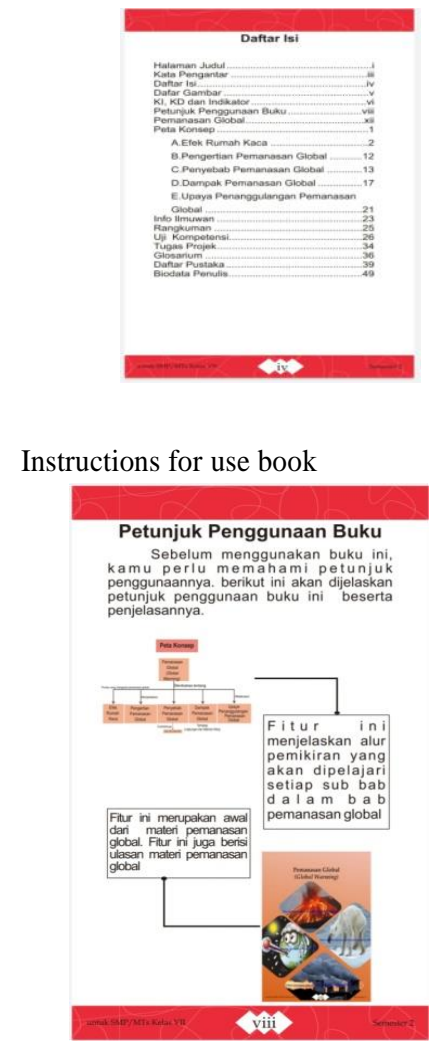

Problems example

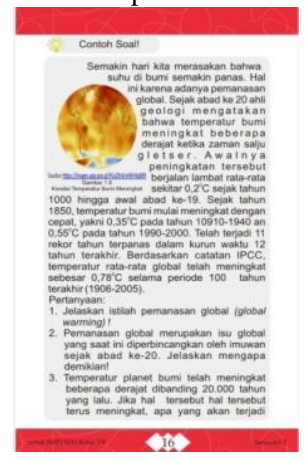

Glossary
Foreword

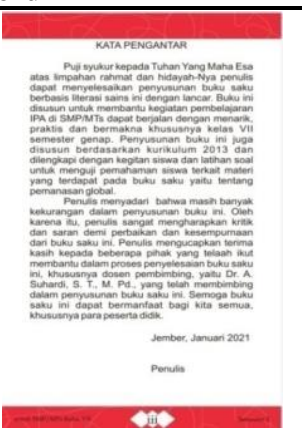

KI, KD and goals

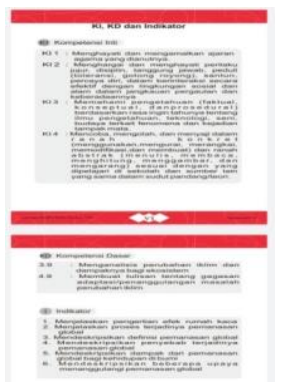

Concept maps

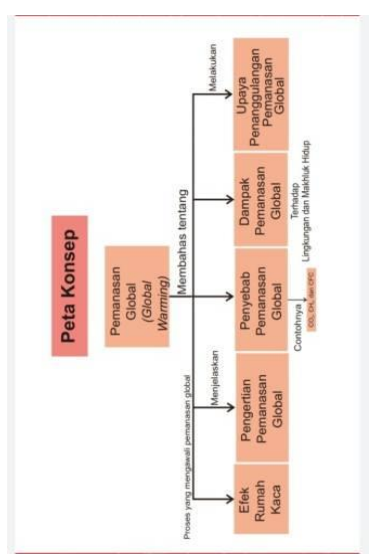

Competence test

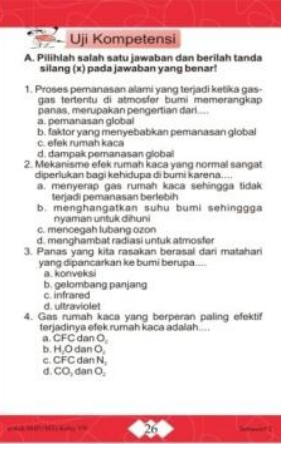

References 


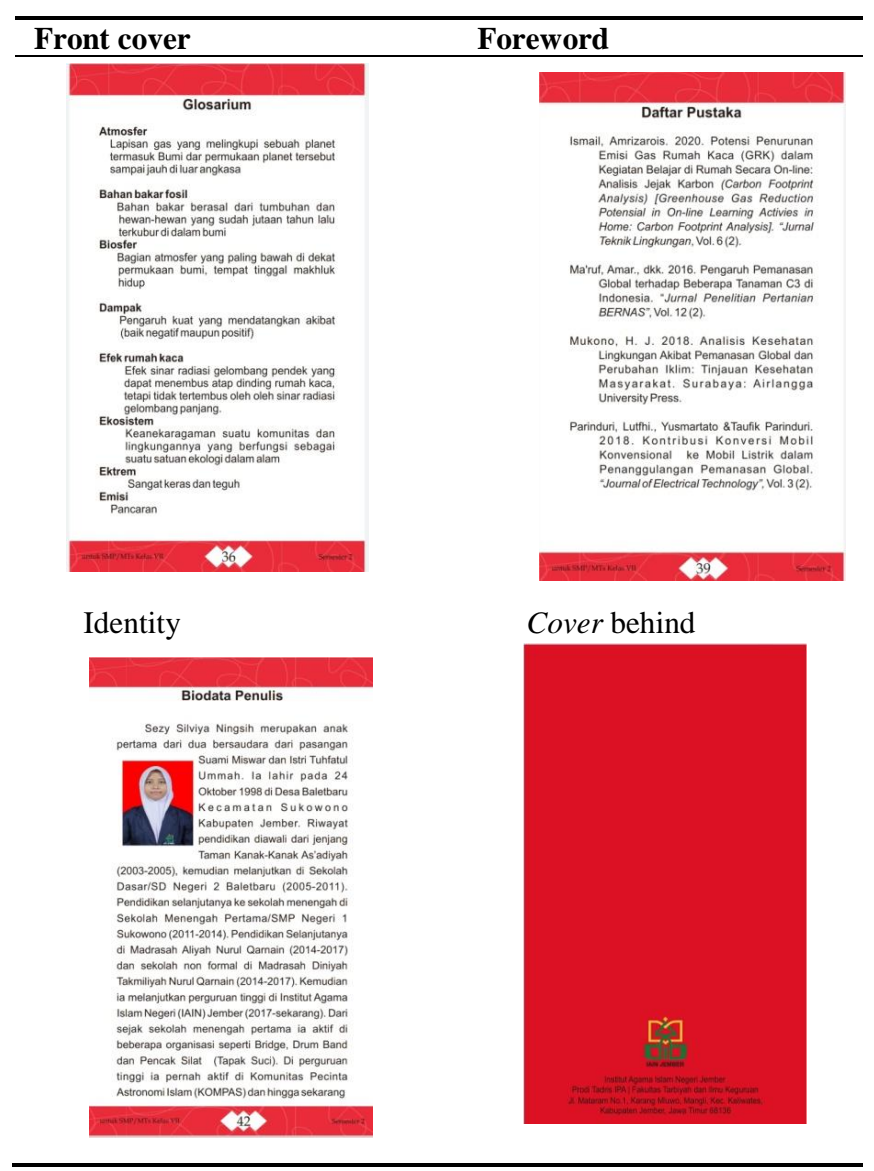

3. Development Stage (develop)

The development stage is the result of a scientific literacy-based pocket book followed by revisions based on input and values from the three validators (material experts, media experts and user experts or teachers) as the basis for improving the products that have been developed.

a. Expert Validation

At this stage, a pocket book based on scientific literacy has been developed and assessed or validated by a team of experts. The experts who are appointed as experts have competence experts and are in accordance with their fields so that they can judge in terms of materials and media.

b. User Validation (Teacher)

User (Teacher) validation carried out by science teachers to determine the suitability of scientific literacy-based pocket books on global warming material as complementary textbooks can support the learning process of students. In this case, the aspects assessed cover all aspects, both in terms of material and media. Aspects assessed by users (teachers) graphic aspects (display, writing, size), content feasibility aspects, material aspects, language feasibility aspects and scientific literacy aspects. Products that have been generated and validated by the validators. From the validator, comments and suggestions are given which are then revised to improve the product. Validation was carried out to determine the level of validity of pocket books based on scientific literacy before being tested on students.

The results of the validation by the validators can be seen in the following table:

Table 5. Validation Results of the Validators

\begin{tabular}{cccc}
\hline No & Validator & Percentage (\%) & Total Average Percentage \\
\hline 1 & Material Validator & 92,38 & \\
2 & Media Validators & 94,28 & $92,12 \%$ \\
3 & User (teacher) & 89,71 & \\
\hline
\end{tabular}

Source: Data processed by researchers 2021 
Based on the table above, it can be seen that the results of the total average percentage of the assessments given by the three validators to a pocket book based on science literacy on global warming material is $92.12 \%$. This states that the development of a science literacy-based pocket book is "very valid".

The researcher presents a picture of the results of the validation assessment by the validators in order to make it easier to see the comparison results from each aspect, namely material experts, media experts and users (teachers).

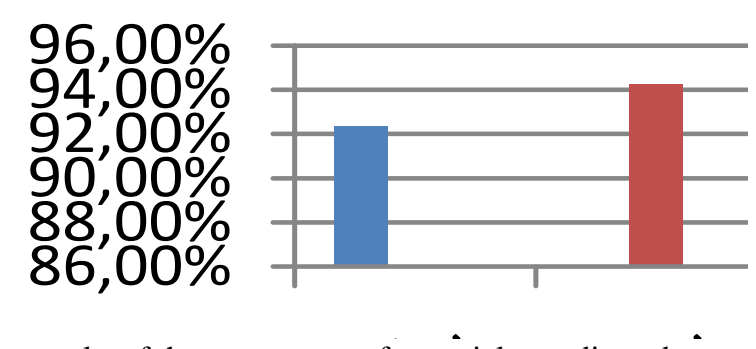

Figure 1. Images of the results of the assessment of materials, media and users (teachers)

After knowing the validity of the scientific literacy-based pocket book, the next step is a development trial conducted by class VII students. Development trials were conducted to determine the students' responses to science literacy-based pocket books. The student response test was carried out in two stages, namely a small-scale trial of 6 students. The results of the smallscale trial stated that the scientific literacy-based pocket book was "very interesting" with an attractiveness rate of $96.45 \%$. While the large-scale trial of $88.24 \%$ stated that science literacybased pocket books were "very interesting".

The researcher presents a graph of the results of the small-scale trial assessment and the large-scale trial results, making it easier to see the comparison results of each of the assessment results.

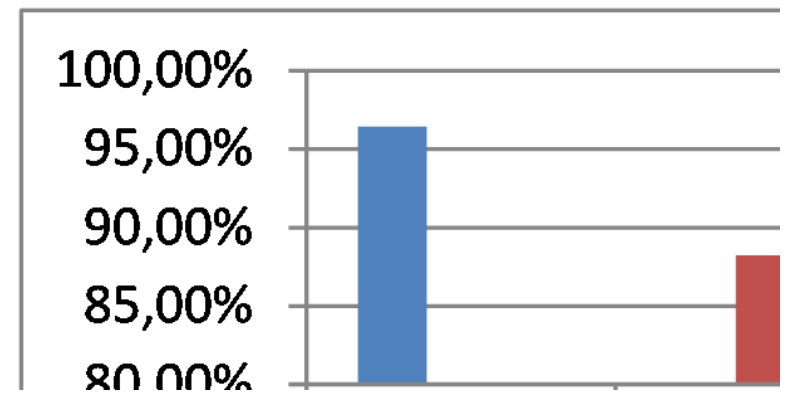

Figure 2. Pictures of Small-Scale and Large-Scale Trial Results

\section{DISCUSSION}

Based on the results of the validation carried out by the validator on the scientific literacybased pocket book that has been developed, the percentage of assessment results from material experts is $92.38 \%$ with the "very valid" category. The results of the percentage of assessments from media experts were obtained at $94.28 \%$, these results stated that pocket books based on scientific literacy were included in the "very valid" category. While the results of the assessment from users (teachers) obtained a percentage value of $89.71 \%$ with the "very valid" category. After that, the average percentage of assessment results from the three validators was $92.12 \%$, these results stated that the scientific literacy-based pocket book on global warming material that had been developed was categorized as very valid and could be used for students.

Judging from these results, the science literacy-based pocket book on global warming material is appropriate for students at the seventh grade junior high school level. The teaching materials also show that they are suitable to be used as learning support books or complementary 
to existing books at school. So that it can help the learning process that will be studied by students, especially on global warming material. This is also equivalent to previous researchers who stated that books can be used and help the learning process because they can contain learning materials so as to convey information from these materials. In addition, the results of previous researchers stated that the pocket books that had been developed were included in the valid category and were ready to be used as teaching materials in schools with a material validity level of material experts and media experts of 76\%. (Mustari \& Sari, 2017).

Pocket books developed by researchers can also be used as teaching materials based on scientific literacy. With teaching materials that contain scientific literacy can increase the level of scientific literacy of students. This statement is equivalent to previous experts who stated the role of teaching materials in the learning process that contains scientific literacy can convey information well. Therefore, teaching materials that contain scientific literacy can improve students' abilities rather than using teaching materials used in schools (Paramita et al., 2016). Scientific literacy has an important role for students because they can face the challenges of the 21 st century and have scientific attitudes such as honesty, discipline and others. Students who have scientific literacy are able to think critically, creatively, logically, and take the initiative in solving problems (phenomena) in society due to the impact of science and technology developments. However, science education (science) can be used as a vehicle for studying individuals about the natural environment by learning science based on what students encounter in everyday life (Permanasari, 2016). Scientific literacy is also a measure of the success or failure of science education in schools (Aqil, 2017).

This scientific literacy-based pocket book also contains pictures that represent global warming material to attract students' reading interest. This was explained by previous experts who stated that pocket books were equipped with pictures and colors to attract students' reading interest (Masita \& Wulandari, 2018). Other experts also stated that teaching materials were made by integrating scientific literacy, containing assignments or activities, presenting interesting illustrations or pictures (Wijayanti, 2019).

The description above is the result of an assessment in the form of quantitative data obtained by filling out a validation questionnaire for a pocket book based on scientific literacy that has been developed. The following are the results of the assessment in the form of qualitative data obtained based on suggestions from the validator to improve the product that has been developed.

According to the expert on science literacy-based pocket book material, from an interesting perspective, the depth and breadth of the material are quite good and can be used for science learning in SMP/MTs. However, the product has had several revisions. The errors that exist in these products include; located on the concept map. The concept maps in scientific literacy-based pocket books are not yet equipped with conjunctions, so the material experts suggest to add conjunctions to the concept maps. In addition to the concept map, there are also word errors that lie in the use of the term deforestation. The product contains the words deforestation which should deforestation and researchers have made improvements to the term so that it is appropriate. In addition, the scientific literacy developed in the pocket book is less visible so it needs to be clarified through additional features. The added features are Did You Know?, Come Think! and Science Information.

The advice from media experts said that scientific literacy-based pocket books are feasible to use with very valid categories. However, the product can be used with revisions. The error found in media experts is that in the typeface used in the product that has been developed, there are still several paragraphs that have not used the typeface Arial but georgia this is due to a lack of accuracy when designing a pocket book product based on scientific literacy that was developed.

Then the qualitative assessment given by the user (teacher) states that in general pocket books can be used for students and a little advice from expert users (teachers), namely on page 10 
of the science literacy-based pocket book it should be replaced with a more representative picture to explain greenhouse effect process.

The next step is a student trial conducted by class VII students (A, B and C) based on the teacher's recommendation. The scientific literacy-based pocket book on global warming material is stated to be very interesting both from small-scale trials and large- scale trials. The results of the

small-scale trial stated that it was very attractive with the attractiveness percentage of $96.45 \%$ and the results of the large-scale trial the attractiveness percentage was $88.24 \%$.

Based on these data, science literacy-based pocket books on global warming material are very interesting and can be used for science learning in SMP/MTs as complementary teaching materials in schools because they contain information related to material and help the learning process. One of the important components used in the learning process is teaching materials because these teaching materials can help smooth learning activities (Irawati, 2018).

Judging from the data from the test results, the student responses from both small and large scales stated that they were very interesting, but there were significant differences in numbers. The small-scale test results are greater than the large-scale test results. This is because in the largescale test the characteristics, learning styles, and levels of understanding of students are different so that in filling out questionnaires and responding to scientific literacy-based pocket books, they are different because they are in accordance with the character of students.

The responses are in the form of suggestions and comments from students. Some students stated that the pocket book developed was interesting and good because it looked attractive, the material and language were easy to understand and the material presented was related to everyday life that students often encountered. Some students also stated that scientific literacy-based pocket books are interesting because they provide benefits for people who read them and are practical enough to carry everywhere. In addition, the material in the pocket book also adds to the knowledge of students.

The scientific literacy-based pocket book developed has several aspects using indicators. This is so that students can understand the contents of the science literacy-based pocket books that were developed and apply them to students' daily lives. Thus, students will be familiar with the aspects listed in the Science Literacy-Based pocket book so as to improve students' scientific literacy. In addition, aspects of scientific literacy used in pocket books are based on learning styles and characteristics of students.

Based on the results of research that has been carried out, it shows that the pocket book based on scientific literacy that was developed can be said to be very valid and can be used in the learning process on global warming material in junior high school/MTs class VII.Then the qualitative assessment given by the user (teacher) states that in general pocket books can be used for students and a little advice from expert users (teachers), namely on page 10 of the science literacy-based pocket book it should be replaced with a more representative picture to explain greenhouse effect process.

The next step is a student trial conducted by class VII students (A, B and C) based on the teacher's recommendation. The scientific literacy-based pocket book on global warming material is stated to be very interesting both from small-scale trials and large- scale trials. The results of the

small-scale trial stated that it was very attractive with the attractiveness percentage of $96.45 \%$ and the results of the large-scale trial the attractiveness percentage was $88.24 \%$.

Based on these data, science literacy-based pocket books on global warming material are very interesting and can be used for science learning in SMP/MTs as complementary teaching materials in schools because they contain information related to material and help the learning process. One of the important components used in the learning process is teaching materials because these teaching materials can help smooth learning activities (Irawati, 2018).

Judging from the data from the test results, the student responses from both small and large scales stated that they were very interesting, but there were significant differences in numbers. The 
small-scale test results are greater than the large-scale test results. This is because in the largescale test the characteristics, learning styles, and levels of understanding of students are different so that in filling out questionnaires and responding to scientific literacy-based pocket books, they are different because they are in accordance with the character of students.

The responses are in the form of suggestions and comments from students. Some students stated that the pocket book developed was interesting and good because it looked attractive, the material and language were easy to understand and the material presented was related to everyday life that students often encountered. Some students also stated that scientific literacy-based pocket books are interesting because they provide benefits for people who read them and are practical enough to carry everywhere. In addition, the material in the pocket book also adds to the knowledge of students.

The scientific literacy-based pocket book developed has several aspects using indicators. This is so that students can understand the contents of the science literacy-based pocket books that were developed and apply them to students' daily lives. Thus, students will be familiar with the aspects listed in the Science Literacy-Based pocket book so as to improve students' scientific literacy. In addition, aspects of scientific literacy used in pocket books are based on learning styles and characteristics of students.

Based on the results of research that has been carried out, it shows that the pocket book based on scientific literacy that was developed can be said to be very valid and can be used in the learning process on global warming material in junior high school class VII.

\section{CONCLUSION}

This research is a type of research Research and Development using a 4-D model by Thiagarajan. The 4- D model has four stages namelyDefine, Design, Develop and Dissiminate. However, this research is only up to the Develop. The results of the study stated that the development of a science literacy-based pocket book on global warming material for class VII SMP/MTs students was declared "very valid" with the total average percentage value of the three validators of $92.12 \%$ and could be used for students. The results of the small-scale response test are $96.45 \%$ and the large-scale response test results are $88.24 \%$ with the criteria of "very interesting".

\section{REFERENCES}

Aqil, D. I. (2017). Literasi sains sebagai konsep pembelajaran buku ajar biologi di sekolah. Jurnal Pemikiran, Penelitian Pendidikan Dan Sains, 5 (2), 161.

Arianto, H., \& Fauziyah, H. N. (2020). Students' Response To the Implementation of Case Based Learning $(\mathrm{Cbl})$ Based Hots in Junior High School. INSECTA: Integrative Science Education and Teaching Activity Journal, 1(1), 45. https://doi.org/10.21154/insecta.v1i1.2058.

Atika, S. (2019). Pengembangan Bahan Ajar Lembar kerja Peserta Didik (LKPD) menggunakan Coreldraw X7 pada Mara Pelajaran Sejarah Kebudayaan Islam (SKI) Materi Dakwah Nabi Muhammad SAW Kelas IV MI. Journal of Chemical Information and Modeling, 53(9), 1689-1699.

Fajar, R. (2018). Pengembangan Buku Saku Digital Materi Bangun Datar. Universitas Islam Negeri Raden Intan Lampung, 15(April), 2017-2019.

Irawati, Hani M. F. S. (2018). Analisis Kebutuhan Pengembangan Bahan Ajar Mata Kuliah Pengantar Profesi Guru Biologi Di Pendidikan Biologi Universitas Ahmad Dahlan Yogyakarta Analysis Of Needs Development Material Learning Program Introductory Profession Of Biological Teacher In Biolog. Jurnal Pembelajaran Biologi, 7, 98. 
Mardatillah. (2018). Pengembangan Buku Saku Identifikasi Tumbuhan pada Materi Keanekaragaman Hayati Kelas X MIA Madani Alauddin Paopao. Skripsi Universitas Islam Negeri Alauddin Makassar.

Masita, M., \& Wulandari, D. (2018). Pengembangan Buku Saku Berbasis Mind Mapping pada Pembelajaran IPA. Jurnal Kreatif, 9(1), 77.

Mustari, M., \& Sari, Y. (2017). Pengembangan Media Gambar Berupa Buku Saku Development Of Image Media In The Form Of Physics Pocketbook On Temperature And Heat For Junior High. 06(April), 113-123. https://doi.org/10.24042/jpifalbiruni.v6i1.1583

Mustika, Erlani. (2019). Desain dan Uji Coba Buku Saku Berbasis Literasi Sains pada Materi Asam Basa. Skripsi Universitas Islam Negeri Sultan Syarif Kasim Riau Pekanbaru, 8(5), 55.

Mustika, T. (2016). Pengembangan alat evaluasi berbasis literasi sains untuk mengukur kemampuan literasi sains siswa bertema energi. Jurusan Fisika Fakultas Matematika Dan Ilmu Pengetahuan Alam.

Nofiana, M., \& Julianto, T. (2018). Upaya Peningkatan Literasi Sains Siswa Melalui Pembelajaran Berbasis Keunggulan Lokal. Biosfer: Jurnal Tadris Biologi, 9(1), 24. https://doi.org/10.24042/biosf.v9i1.2876.

Paramita, A. D., Rusilowati, A., \& Semarang, U. N. (2016). Pengembangan Bahan Ajar Berbasis Literasi Sains Materi Suhu dan Kalor. 500, 58-67.

Permanasari, A. (2016). STEM Education: Inovasi dalam Pembelajaran Sains. 23-34.

Prastowo, A. (2016). Pengembangan Bahan Ajar Tematik. Jakarta: KENCANA, 413-414.

Salyani, R., Amsal, A., \& Zulyani, R. (2018). Pengembangan Buku Saku Pada Materi Reaksi Reduksi Oksidasi ( Redoks ) di MAN Model Banda Aceh. 02(01), 7-14.

Setyawan, E. (2018). Upaya Meningkatkan Hasil Belajar Menggunakan Perangkat Lunak Pengolah Kata Word 2007 Untuk Menyajikan Informasi Melalui Metode Simulasi Pada Siswa Kelas Viii B Semester 1 Smp Negeri 7 Sukoharjo Tahun 2017/2018. Jurnal Ilmiah Edunomika, 2(01), 118-128. https://doi.org/10.29040/jie.v2i01.182.

Setyosari, P. (2013). Metode Penelitian Pendidikan dan Pengembangan Edisi Keempat. Jakarta: KENCANA, 247.

Sudaryono. (2016). Metode Penelitian Edisi Pertama. Jakarta: KENCANA, 77.

Sugiyono. (2017). Metode Penelitian Kuantitatif, Kualitatif dan $R \&$ D. Bandung; ALFABETA, 102.

Toharudin, Uus D. (2011). Membangun Literasi Sains Peserta Didik. Bandung: Humaniora, 1. Wijayanti, T. S. (2019). Pengembangan Buku Saku Biologi Berorientasi Keunggulan Lokal untuk Meningkatkan karakter Peserta Didik. JUPE: Jurnal Pendidikan Mandala, 4(5), 146.

Yaumi. (2017). Penerapan Perangkat Model Discovery Learning pada Materi Pemanasan Global untuk Melatihkan Kemampuan Literasi Sains Siswa SMP Kelas VII Yaumi Mahasiswa Program Studi Pendidikan Sains FMIPA UNESA, e-mail: yaumi.sains15@gmail.com Wisanti Dosen Jurusan Bio.05, 38-45.

Yuliani, F. (2015). Pengembangan Buku Saku Pemanasan Global untuk SMP. Skripsi Universitas Negeri Semarang.

Yuliati, Y. (2017). Literasi Sains dalam Pembelajaran IPA. Cakrawala, Jurnal Vol, Pendas Juli, Edisi, 3(2), 21-28. 